\title{
WHAT DOES THE DISTRIBUTION OF STYGOBIOTIC COPEPODA (CRUSTACEA) TELL US ABOUT THEIR AGE?
}

\author{
KAJ NAM POVE RAZŠIRJENOST STIGOBIONTSKIH \\ CEPONOŽNIH RAKOV (CRUSTACEA: COPEPODA) \\ O NJIHOVI STAROSTI?
}

\author{
David C. CULVER ${ }^{1} \&$ Tanja PIPAN ${ }^{2}$
}

\begin{abstract}
UDC 595.3-15

591.5:595.3

David C. Culver \& Tanja Pipan: What Does the Distribution of Stygobiotic Copepoda (Crustacea) Tell Us About Their Age? Geographic distribution of stygobionts is often used to estimate age of a group by assuming vicariant speciation with little or no subsequent dispersal. We investigated the utility of using distributional data for Slovenian stygobiotic copepods by assuming that dispersal is a way to measure age of a species. We list some species of Copepoda that, on the basis of their range and frequency of occupancy within their range, should be older. Body size is not predictor either of range or frequency of occupancy. Key words: Speleobiology, Copepoda, stygobionts, dispersal biogeography.
\end{abstract}

Izvleček

UDK 595.3-15

\begin{abstract}
David C. Culver \& Tanja Pipan: Kaj nam pove razširjenos stigobiontskih ceponožnih rakov (Crustacea: Copepoda) o njihovi starosti?

Ob predpostavki, da je nastajanje novih vrst posledica vikariance, brez naknadne disperzije, se za ocenjevanje starosti živalskih skupin pogosto uporablja geografska razširjenost stigobiontov. Ob domnevi, da je disperzija merilo za določanje starosti vrst, smo proučevali primernost podatkov o razširjenosti stigobiontskih kopepodov v Sloveniji. Na osnovi analize obsega naselitve in pogostosti naseljevanja znotraj območja smo v prispevku priložili seznam nekaterih vrst ceponožnih rakov, ki naj bi bile evolucijsko starejše. Telesna velikost ne določa obsega naselitve in pogostosti pojavljanja.
\end{abstract}

Ključne besede: speleobiologija, Copepoda, stigobionti, disperzijska biogeografija.

\section{INTRODUCTION}

The distribution of stygobionts has often been used to infer the age of a fauna. The general procedure has been to assume that little or no migration has occurred, and that the extant distribution represents the site of original colonization and isolation in subterranean habitats. The vicariance biogeographic view, now dominant in modern biogeography (e.g., Crisci, Katinas, and Posadas 2003) largely supplanted the old idea of centers of origin with species dispersing out from this central place (Matthew
1915). Given the reduced opportunities for dispersal of subterranean animals, it is not surprising that there have been a number of studies that show a correspondence between ancient shorelines and current distributions, especially Tethyan and Paratethyan distributions (Culver and Pipan in press). In some cases, it has been possible to match distributions to historical events and to obtain support from molecular clock data (see Verovnik, Sket, and Trontelj 2004). However, not all subterranean dis-

\footnotetext{
${ }^{1}$ Department of Biology, American University, 4400 Massachusetts Ave., NW, Washington D.C., U.S.A.; e-mail: dculver@american.edu

${ }^{2}$ Karst Research Institute ZRC-SAZU, Titov trg 2, SI-6230 Postojna, Slovenia; e-mail: pipan@zrc-sazu.si Received/Prejeto: 27.11.2006
} 
tributions can be explained solely by vicariance. A particularly interesting example is the cirolanid isopod $A n$ trolana lira Bowman. In general, subterranean cirolanids are found near to marine shores (Botosaneanu, Bruce, and Notenboom 1986), suggesting a marine ancestor with vicariant isolation. But, A. lira is found in caves in the Appalachian Valley of Virginia and more than 200 $\mathrm{km}$ from not only the present ocean shore, but from any ocean dating back at least to the Paleozoic (Holsinger, Hubbard, and Bowman 1994).

In this contribution, we take a dispersalist rather a vicariance view of subterranean biogeography. We consider a model of colonization and isolation as follows. A species colonizes and is isolated in a subterranean site. As adaptation occurs, the species occupies more sites in the vicinity of the colonization. That is, the frequency of occupancy of subterranean sites increases. In the next stage, the species expands its range, with a high occupan- cy of suitable sites in its range. Finally, as other species also evolve, the original species may be out-competed or it may become specialized in response to competition. In this scenario, it will then occupy a lower frequency of sites within its range. Thus, we can rank the ages of species in increasing age as follows:

1. Species with small ranges and occupying few (sometimes only one) sites

2. Species with small ranges but occupying a high frequency of sites within its range

3. Species with large ranges and occupying a high frequency of sites within its range

4. Species with large ranges and occupying a low frequency of sites within its range.

We examine this hypothesis using distributional data of subterranean copepods from Slovenia (see Pipan 2005), and make assess the utility of this approach.

\section{METHODS AND MATERIALS}

From information in Pipan (2005) and Culver, Pipan, and Schneider (in press) we generated list of stygobiotic copepods from seven Slovenian caves, with information on ranges, frequency of occupancy of well-sampled caves, and average body size. Ranges were categorized into three groups:

1. Slovenian endemics

2. Balkan endemics

3. European endemics

4. Cosmopolitan species

To measure frequency of occupancy, we used data from Pipan (2005), which was intensive enough that it is likely that most species were found (Pipan and Cul- ver in press). Body sizes were taken from original species descriptions and direct measurement by TP. Data were available for 37 species.

Analysis was done by grouping ranges into two categories (Small-categories 1 and 2 and Large-categories 3 and 4), frequency of occupancy into two categories (Low-1 to 3 caves and High -4 to 7 caves), and size into two categories (Small-less than the overall mean of 0.61 and large-greater than or equal to the overall mean of 0.61 ). The resulting $2 \mathrm{X} 2$ contingency tables were analyzed for independence using Fisher's Exact Test in JMP $^{\mathrm{TM}}$ (Sall, Creighton, and Lehman 2005).

\section{RESULTS}

Available data for the 37 species of stybobiotic copepods are shown in Table 1. In Table 2, all species are categorized into four groups based on range and occupancy. There was no significant difference between observed and expected although there was a small excess of species with large ranges that were also found in a high frequency of caves. Those species hypothesized to be the oldest (large ranges, low occupancy) were:

- Acanthocyclops kieferi

- Acanthocyclops venustus stammeri

- Diacyclops clandestinus
- Dicyclops languidoides

- Elaphoidella elaphoides

- Morariopsis scotenophila

The group hypothesized to be the next oldest are those with large ranges and high occupancy:

- Elaphoidella jeanneli

- Bryocamptus balcanicus

- Acanthocyclops venustus

- Parastenocaris nolli alpina 
Tab. 1: Stygobiotic copepod species found in seven well-sampled caves in Slovenia. See Pipan (2005) and Culver et al. (in press).

\begin{tabular}{|c|c|c|c|}
\hline Species Name/Taxonomic Authority & Mean Body Size & No. Caves Occupied & Range \\
\hline Acanthocyclops kieferi (Chappuis, 1925) & 0.73 & 2 & 3 \\
\hline Acanthocyclops venustus (Norman \& Scott, 1906) & 1.07 & 1 & 3 \\
\hline Acanthocyclops venustus stammeri (Kiefer, 1930) & 1.07 & 5 & 3 \\
\hline Bryocamptus balcanicus (Kiefer 1933) & 0.40 & 4 & 3 \\
\hline Bryocamptus borus Karanovic \& Bobic, 1998 & & 1 & 2 \\
\hline Bryocamptus pyrenaicus (Chappuis, 1923) & 0.80 & 7 & 3 \\
\hline Bryocamptus sp. & & 2 & 1 \\
\hline cf. Stygepactophanes sp. & 0.35 & 3 & 1 \\
\hline Diacyclops charon (Kiefer, 1931) & 1.00 & 7 & 2 \\
\hline Diacyclops clandestinus (Kiefer, 1926) & 0.40 & 3 & 4 \\
\hline Diacyclops hypogeus (Kiefer, 1930) & 0.50 & 2 & 1 \\
\hline Diacyclops languidoides (Lilljeborg, 1901) & 0.80 & 3 & 4 \\
\hline Diacyclops slovenicus (Petkovski, 1954) & 0.68 & 3 & 1 \\
\hline Echinocamptus georgevitchi (Chappuis, 1924) & 0.70 & 1 & 2 \\
\hline Elaphoidella cvetkae Petkovski, 1983 & 0.75 & 4 & 2 \\
\hline Elaphoidella elaphoides (Chappuis, 1924) & 0.60 & 1 & 3 \\
\hline Elaphoidella franci Petkovski, 1983 & 0.64 & 1 & 1 \\
\hline Elaphoidella jeannelli Chappuis, 1928 & 0.60 & 4 & 3 \\
\hline Elaphoidellakarstica Dussart \& Defaye (1990) & & 1 & 1 \\
\hline Elaphoidella sp. A & & 2 & 1 \\
\hline Elaphoidella sp. B & & 2 & 1 \\
\hline Elaphoidella stammeri Chappuis, 1936 & 0.62 & 4 & 1 \\
\hline Maraenobiotus cf. brucei & 0.60 & 1 & 1 \\
\hline Metacyclops postojnae Brancelj, 1990 & $>0.61$ & 1 & 2 \\
\hline Moraria sp. A & & 2 & 1 \\
\hline Moraria sp. B & & 1 & 1 \\
\hline Moraria stankovitchi Chappuis, 1924 & 0.55 & 2 & 2 \\
\hline Morariopsis dumonti Brancelj, 2000 & 0.39 & 2 & 1 \\
\hline Morariopsis scotenophila (Kiefer 1930) & 0.49 & 3 & 4 \\
\hline Nitocrella sp. & 0.50 & 2 & 1 \\
\hline Parastenocaris cf. andreji & 0.40 & 2 & 1 \\
\hline Parastenocaris nolli alpina (Kiefer, 1938) & 0.42 & 5 & 3 \\
\hline Parastenocaris sp. A & 0.40 & 2 & 1 \\
\hline Parastenocaris sp. B & 0.40 & 4 & 1 \\
\hline Parastenocaris sp. C & 0.40 & 2 & 1 \\
\hline Speocyclops infernus (Kiefer 1930) & 0.47 & 6 & 2 \\
\hline Troglodiaptomus sketi Petkovski, 1978 & 0.88 & 3 & 2 \\
\hline
\end{tabular}

We investigated whether there was a body size bias for occupancy or range size. Smaller copepods might be able to disperse more easily but they may also be more subject to the vagaries of water movement in epikarst ( $\mathrm{Pi}-$ pan and Culver 2006). In any case, there was no relationship between frequency of occupancy and body size and no relationship between range and body size (Table 3 ). 
Tab. 2: Number of species of stygobiotic copepods in categories of large and small range and high and low frequency of site occupancy. Numbers in parentheses are the expected numbers. Observed and expected numbers do not significantly differ $(p=0.21$, Fisher's Exact Test).

\begin{tabular}{|l|c|c|}
\hline & High Occupancy & Low Occupancy \\
\hline Large Range & $4(2.4)$ & $5(6.6)$ \\
\hline Small Range & $6(7.6)$ & $22(20.4)$ \\
\hline
\end{tabular}

Tab. 3: Number of species of stygobiotic copepods in categories of high and low frequency of site occupancy $(A)$, large and small range $(B)$ and body size. Numbers in parentheses are the expected numbers. Neither association was statistically significant ( $p=0.71$ for $A, p=0.71$ for B, Fisher's Exact Test).

A.

\begin{tabular}{|l|c|c|}
\hline & High Occupancy & Low Occupancy \\
\hline Large Body Size & $5(4.3)$ & $8(8.7)$ \\
\hline Small Body Size & $5(6.7)$ & $12(11.3)$ \\
\hline
\end{tabular}

B.

\begin{tabular}{|l|c|c|}
\hline & Large Range & Small Range \\
\hline Large Body Size & $5(4.5)$ & $8(8.5)$ \\
\hline Small Body Size & $5(5.5)$ & $11(10.5)$ \\
\hline
\end{tabular}

Finally, we investigated the taxonomic position of the putative older species, i.e., those with larger ranges. Of the ten species listed above, five are cyclopoids and five are harpacticoids. There is an excess of large ranged cyclopoids but the difference was only significant at p 0.10 (Table 4). Acanthocyclops is especially noteworthy. All three stygobiotic species (A. kieferi, A. venustus, and $A$. venustus stammeri) had large ranges. In contrast none of the three species of Moraria (M. stankovitchi, sp. $A$, and sp. B) have large ranges. The lone calanoid species (Troglodiaptomus sketi) also has a small range.

Tab. 4: Relationship between range and taxonomic group (Cyclopoida vs. Harpacticoida). Expected numbers are given in parentheses. The relationship was marginally significant ( $p \sim 0.10$, Fisher's Exact test).

\begin{tabular}{|l|c|c|}
\hline & Large Range & Small Range \\
\hline Cyclopoida & $5(2.8)$ & $5(7.2)$ \\
\hline Harpacticoida & $5(7.2)$ & $21(18.8)$ \\
\hline
\end{tabular}

\section{DISCUSSION}

We have created a list of copepod species that, according to the hypothesis outlined in the introduction, should be older than other stygobiotic copepod species discussed in this study. Unfortunately, we know of no detailed phylogeny that would allow for such a comparison but we think that it would make for a very interesting study to do so. What is known about copepod phylogeny is that the Cyclopoida seem to be a more recent group than the Harpacticoida, accoding to the phylogeny of Huys and Boxshall (1991). The fact that cyclopoids are over-represented among species with large ranges (Table 4) contradicts the hypothesis put forward. Of course, just because cyclopoids as a group are younger does not mean that the species are all younger than harpacticoids. Alternatively, it may be that harpacticoids are in general being outcompeted by cyclopoids, and this has resulted, not only in reduction in occupancy frequency, but also in range contraction.

We think that examination of the kinds of distribution patterns (range size and occupancy) discussed here will yield interesting results. This analysis would enrich phylogeography studies as well as provide additional hypotheses about the origin and evolution of subterranean groups.

\section{ACKNOWLEDGEMENTS}

The authors were supported by funds from the Center for Subterranean Biodiversity of the Karst Waters Insti- tute and the Ministry of Higher Education, Science, and Technology of the Republic of Slovenia. 


\section{REFERENCES}

Botosaneanu, L., N. Bruce, \& J. Notenboom., 1986: Isopoda: Cirolanidae, pp. 412-421, in L. Botosaneanu [ed.] Stygofauna Mundi. E.J. Brill, Leiden, The Netherlands.

Crisci, J.V., L. Katinas, \& P. Posadas., 2003: Historical Biogeography. An Introduction. p. 250, Harvard Univ. Press, Cambridge.

Culver, D.C., T. Pipan., \& K. Schneider., in press: Vicariance, dispersal, and scale in the aquatic subterranean fauna of karst regions. Freshwater Biology

Culver, D.C., \& T. Pipan., in press: Subterranean ecosystems. In S.A. Levin [ed.] Encyclopedia of Biodiversity, second edition. Elsevier, Amsterdam.

Holsinger, J. R., D. A. Hubbard, Jr , \& T. E. Bowman., 1994: Biogeographic and ecological implicationd of newly discovered populations of the stygobiont isopod crustacean Antrolana lira Bowman (Cirolanidae). Journal of Natural History 28, 1047-1058.

Huys, R., and G. Boxshall., 1991: Copepod evolution. p. 468, The Ray Society, London,

Matthew, W.D., 1915: Climate and evolution. Annals of the New York Academy of Sciences 24, 171-318.
Pipan, T., 2005: Epikarst - a Promising Habitat. 100 p. Karst Researach Institute at ZRC-SAZU, ZRC Publishing, Postojna.

Pipan, T., \& D.C. Culver., 2006: Copepod distribution as an indicator of epikarst system connectivity. Hydrogeology Journal

Pipan, T., \& D.C. Culver., in press: Regional species richness in an obligate subterranean dwelling faunaepikarst. Journal of Biogeography.

Sall, J., L. Creighton, \& A. Lehman., 2005: JMP Start Statistics. Brook/Cole-Thomson Learning, Belmont, California.

Verovnik, R., B. Sket, \& P. Trontelj., 2004: Phylogeography of subterranean and surface populations of water lice Asellus aquaticus (Crustacea: Isopoda). Molecular Ecology 13, 1519-1532. 
